\title{
An Examination of University Students' Uses of English and Arabic in One Syrian Higher Education Setting, Drawing on Atkinson's (2004) Model of Overlapping Cultures
}

\author{
Abdulkader Abdulkader ${ }^{1} \&$ Janet Laugharne ${ }^{2}$ \\ ${ }^{1}$ English Department, Aleppo University, Syria \\ ${ }^{2}$ School of Education, Cardiff Metropolitan University, Cardiff, Wales, UK \\ Correspondence: Janet Laugharne, School of Education, Cardiff Metropolitan University, Cyncoed Road, Cardiff, \\ CF23 6XD, Wales, UK. Tel: 44-029-2041-6499. E-mail: jlaugharne@ cardiffmet.ac.uk
}

Received: May 13, 2016

Accepted: August 10, 2016

Online Published: August 15, 2016

doi:10.5430/elr.v5n3p38

URL: http://dx.doi.org/10.5430/elr.v5n3p38

\begin{abstract}
This article contributes to discussion on uses of English and other languages in international higher education. The authors draw on Atkinson's (2004) model of five overlapping cultures (national, professional-academic, student, youth and classroom) in an educational setting to examine students' uses of English and Arabic in one higher education institution in Syria. Although modest in scale, this is of particular value as there is little existing data on this topic. Fifteen semi-structured interviews were conducted in Arabic, translated into English and analysed within the computer programme NVivo. The students' responses about their language use were examined with a focus on student culture as this overlapped with the other cultures in Atkinson's (2004) model. Findings are presented in relation to: i.) national culture and youth culture; and ii.) professional academic culture and classroom culture. While recognising there are dynamic connections between all these cultures, we found that student culture overlapped closely in language use onto Arabic for national culture and some aspects of youth culture, while it overlapped onto English for professional academic and classroom culture. One key finding was the widespread aspiration to travel and study abroad. This was strongly associated with the use of English and was particularly striking, since few of the students had travelled outside Syria. A second finding was the varied and enterprising way by which students engaged with the Internet and other media to support their learning of English. This contrasted strongly with the more formal way by which they were taught English.
\end{abstract}

Keywords: Arabic, English, EAP, Higher education, Syria, Students

\section{Introduction}

There is current, important discussion on uses of English and other languages in international higher education (De Witt, 2011; Knight, 2015). In this article we aim to contribute to the debate through an in-depth examination of language use by students in one Syrian university setting. Our research draws on Atkinson's (2004) model of five overlapping cultures in an educational setting, which we employ as a framework to examine students' reported uses of English and Arabic. This is a focus of interest which has not received much previous attention. It explores Atkinson's model in a region where English is not a first or second national language.

The conceptual complexity carried in the words 'language' and 'culture' is well recognized, compounded by the fact that these are dynamic and constantly changing terms. At different periods of time, they variously have been defined as homogenous concepts allied to particular societies, or problematized in relation to an individual's sense of identity. Other studies have suggested a middle ground, encompassing both large-scale, national dimensions and sub-levels, such as peer group or family affiliations. Atkinson's (2004) model of overlapping cultures in an educational setting sits in this third camp and is the approach we adopt in this paper.

Discussions of language and culture are also increasingly viewed in the global and local scale; and in many different contexts. All this makes the study of the interrelationship between English and other languages a rich and varied one (Jackson, 2014; Jenkins, 2015). In our research, with data collected in an English language classroom in one Syrian university, we wanted to examine the boundaries between the cultures in Atkinson's model and the ways they related one to another. We were interested to find out how the students perceived and managed these overlapping cultures. 
The backdrop to our study then is the increasing plurality of language use, whereby individuals negotiate several languages for different purposes. Models such as that by Mahboob (2015) attempt to encapsulate this in a dynamic approach, by looking at the local and the global, the mode of expression, the use and the users. And, of course, there are many debates about the dominance of English as a global language. Altbach (2015),considering international higher education, underlines some of the important issues.

Deep inequalities undergird many of the current trends in globalization and internationalization in higher education, and they too need to be understood as part of the picture. A few countries dominate global scientific systems, the new technologies are owned primarily by multinational corporations or academic institutions in the major Western industrialized nations, and the domination of English creates advantages for the countries that use English as the medium of instruction and research. (p.6)

Similarly, Albirini (2016), writing about modern Arab sociolinguistics in the Middle Eastern region, comments:

for language planners...the main question is how language policies can strike a balance between maintaining the role of Arabic education and society, while still promoting English/French for national development, global communication and international economic competitiveness. (p. 151)

These shifting ideologies and concepts were present in our thinking as we carried out our research. We were also mindful that there is an increasing interest in examining the learner's perspective on their language use and how the different languages they speak interrelate (Atkinson \& Sohn, 2013; Lightbown \& Spada, 2013).

\section{English and Arabic in the Education System in Syria}

Arabic is the language of Syria and neighbouring regions and postgraduate studies are conducted in Arabic, following a national policy introduced to safeguard the language from the inroads of global English (Crystal, 2012, 2013; Martí, 2005). Throughout the pre-university education system, Arabic is the language of instruction. However, it can be noted that private schools and universities have been an increasing feature of the education context in recent years; and the language of instruction in many of these is English.

Counterbalancing the Syrian government policy for safeguarding Arabic is the requirement to teach English as a foreign language in all sectors of society. Students start to learn English from year one, at age six. This continues up to, and including, higher education. English non-specialists have to pass a proficiency test in English before being accepted for most public jobs, especially teaching. Those who wish to pursue their postgraduate studies must also pass a proficiency test in English. Both tests are automated, multiple-choice written tests at intermediate to upper-intermediate level. The elements tested are normally everyday English, grammar, vocabulary, and reading comprehension. Speaking and listening are not tested.

Study University (pseudonym) provides additional language support to its students, mainly through the Higher Institute of Languages. Within the Institute there is a centre for teaching English, as well as other foreign languages, to students and professionals. The assessment system followed in all courses is an internal assessment system. Several types of English for Specific Purposes (ESP) are taught in the Institute: English for Academic Purposes (EAP) and English for Vocational Purposes (EVP), alongside other types of English language teaching, for example communication courses and Business English courses.

At Study University, EAP teaching considers the written language skills: reading and writing. Written exams are the method of student assessment. Other aspects of EAP are not developed in teaching: for example, academic essays, seminars, presentations and research articles. Further, the cultural aspects of EAP, such as communicating with native speakers and reading a newspaper, are not evident, as the teaching is designed for home students (Abdulkader, 2009).

There has been considerable improvement in learning and teaching English in the Syrian higher education system, as well as increased interest in English as a language used in international contexts. Research at times has highlighted different aspects of these areas (Abdulkader \& Laugharne, 2009, where it is recognised the key role English has to play in the drive for internationalisation in higher education and to meet the needs of globalisation.

\section{Atkinson's Model of Overlapping Cultures}

Atkinson (2004) comments that 'studies of EAP need to include a better conceptualisation of culture' (p. 277). He says that they have traditionally presented what he calls 'received culture', which he defines, drawing on Gupta and Ferguson (1997), as 'the idea that a world of human difference is to be conceptualised as a diversity of separate societies, each with its own culture' (p.277). Atkinson goes on to connect this discussion of culture with education, saying 'the idea of classrooms as cultures has been an important concept' (p.285). From this, he developed a 
modified version of Holliday's (1994) model of overlapping cultures, applied in education settings. This model is shown in Figure1. Atkinson describes several overlapping 'small cultures' of different sizes and levels of interaction. Five cultures are identified: national, professional-academic, student, classroom and youth. Further, he notes that small cultures have crucial roles to play in understanding the dynamic of any particular educational setting. For example, student culture has special practices and norms in any education situation, and these overlap with, but are not subsumed under, national cultural norms and practices and those of youth culture. Youth culture practices and norms themselves partly overlap with national culture, but are by no means contained by it, since youth culture goes beyond national boundaries, and so on. We examine this concept in detail during our analysis.

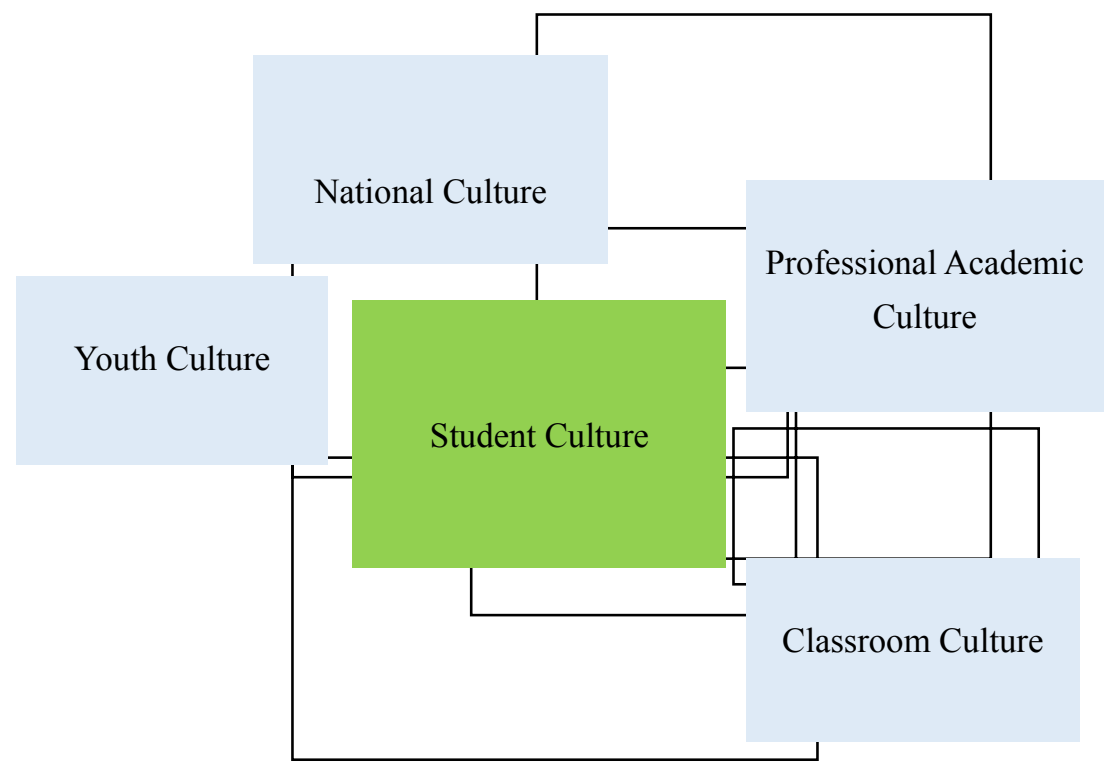

Figure 1. Five Overlapping Cultures in an Educational Setting (Atkinson, 2004 p. 285, drawing on Holliday, 1994)

This view of varying cultures within education is echoed in the literature. For example, Sowden (2007) noted Teachers need to be aware not only of the cultures of their students and their environment, but also of the cultures that they themselves bring to the classroom. (p.305)

Montgomery (2007) also commented that 'social and cultural contexts of both students and staff are ...influential in student learning and development' (p.22). This applies to all learning and teaching contexts, of course, but is particularly relevant where language learning is involved.

We considered these five overlapping cultures in connection with uses of, and perception about, English and Arabic in designing our research. We assumed that in the drive for the internationalisation of higher education, a large number of references to English would occur relative to student culture, although we were also aware of the national policy to study through the medium of Arabic. A similar rationale for uses of English and Arabic would be in place, we thought, in relation to professional academic culture and classroom culture. We expected high levels of reference to English for youth culture when speaking about film, Internet and other media.

We anticipated the students might report less English in relation to national culture because of the social, political and religious affiliations to Arabic in the Middle East as a whole. We thought that aspects of youth and student culture would also show a greater use of Arabic than English, where it overlapped with national culture.

\section{Methodology}

\subsection{Research Design and Data Collection}

Semi-structured interviews were conducted with fifteen students at Study University. The students were broadly at the same level of English, as they had to pass to an official placement test at the Higher Institute of Languages. They then joined a paid seven-week communication course at the Institute. The students were taught by the first author, who conducted the interviews. They gave verbal permission to be interviewed. Pseudonyms are used to discuss their responses. The students were from different specialisations, as shown in the following table. 
Table1. Range of discipline areas in the interview group

\begin{tabular}{|c|c|c|}
\hline Discipline & Number of students & $\begin{array}{l}\text { Students names } \\
\text { (pseudonyms) }\end{array}$ \\
\hline English Language and Literature & 2 & $\begin{array}{l}\text { Nurah } \\
\text { Malikah }\end{array}$ \\
\hline Medicine & 2 & $\begin{array}{l}\text { Faris } \\
\text { Bahiyah }\end{array}$ \\
\hline Environmental Engineering & 2 & $\begin{array}{l}\text { Shareef } \\
\text { Asif }\end{array}$ \\
\hline Technical Engineering & 2 & $\begin{array}{l}\text { Marwan } \\
\text { Najid }\end{array}$ \\
\hline Mechanical Engineering & 1 & Rafiq \\
\hline Information Engineering & 1 & Rashidah \\
\hline Civil Engineering & 1 & Anwar \\
\hline Control Engineering & 1 & Mukhtar \\
\hline Chemistry & 1 & Wahid \\
\hline Economics & 1 & Ramlah \\
\hline Geology & 1 & Akil \\
\hline
\end{tabular}

All interviews were conducted in Arabic, audiotaped and transcribed verbatim by the first author. A copy of the interview schedule can be seen in the Appendix. The interviews were translated into English in discussion with the second author, before they were imported into the qualitative analysis programme, NVivo, and coded. The coding process was based on Atkinson's (2004) model of five overlapping cultures in an educational setting: national, professional-academic, student, classroom and youth.

Our focus of study started with student culture in relation to uses of Arabic and English. We then explored the ways in which student culture overlapped with the other cultures in Atkinson's model.

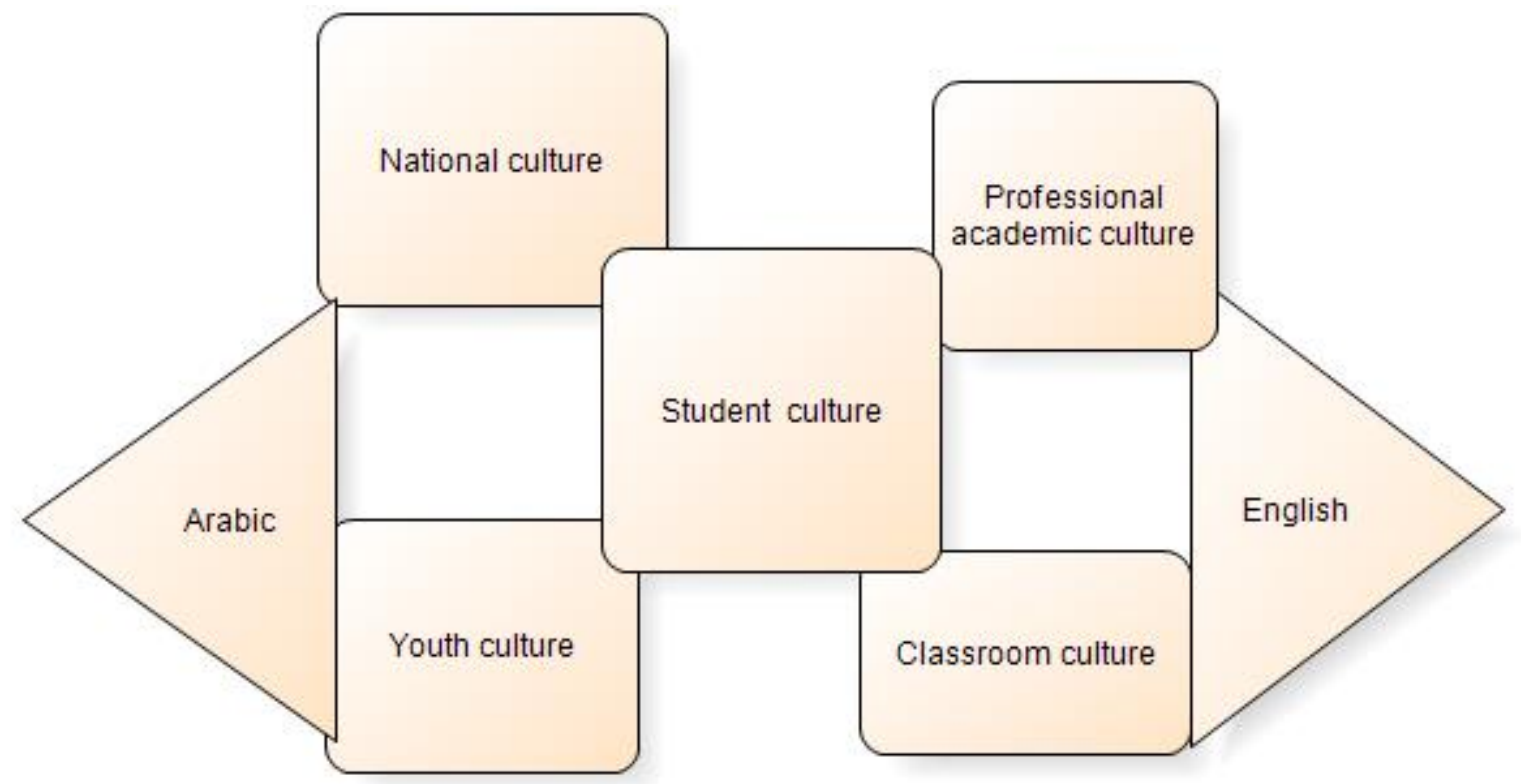

Figure 2. Model of Syrian students' use of English and Arabic within Atkinson's (2004) concept of overlapping cultures in an education context 


\subsection{Data Analysis Procedure}

As our source of evidence was student interviews, we centred our analysis in student culture. We were excited to see how uses of English and Arabic would be reported by the students. The extent to which the overlapping of cultures of Atkinson's 2004 model ran along language fault lines was of particular interest to us. For the purposes of organisation and clarity, discussion of the five cultures is discussed in two main sections. The first considers student culture in relation to national culture and youth culture, while the second section considers student culture in relation to professional academic culture and classroom culture. Broadly, the first was more external to the University and the latter more internal to it. It is recognised, of course, that these are blurred boundaries and dynamic connections exist between all five cultures in the model.

\section{Student Culture in Relation to National Culture and Youth Culture}

In this section of the data analysis, it was evident that the students as a group shared several features with each other, which would be less common in many other student cultures, apart perhaps from some of the other countries in the Middle East. For example, about half of the students had not travelled outside Syria. None had been to a country where English was a national language; one had been to Russia and another to Turkey. The remainder had travelled to countries in the Middle East (Egypt, Palestine, Saudi Arabia, Lebanon, Kuwait). This situation was undoubtedly exacerbated by the conflict in Syria at the time of data collection. (Note 1) Some students referred to this, as, for example, Akil:

I am a university graduate of geology. I intend to continue my study. I am signed up for a Master's degree, but because of the current crisis, I have stopped my study. God willing, I am planning to continue my study abroad.

However, despite their limited travel experience, most of the students expressed an interest in going abroad to study or to work. The following quotations illustrate this aspiration:

I am now fourth year environmental engineering. I expect to continue for MA, most probably abroad. (Shareef)

[I am] a student of information engineering, third year. I hope to graduate and get a job opportunity in my specialization and if I get a job abroad, it will be better. (Rashidah)

Hopefully I will be fourth year shortly in English language and literature. After graduation, I am thinking about travelling abroad and working with English. Travel to foreign countries. (Nurah)

These quotations show how the student culture is marked by an ethic of academic aspiration and personal development alongside an ambition to gain experience abroad, through study or work. In this respect, Syrian student culture maps onto that of many students around the world, who aim to gain new skills, qualifications and experiences through travel.

Another cohering feature in the data was of the commitment to hard work and self-improvement, combined with a devout wish (God willing):

As a student, I have to make friends with [other] hard-working students. It is often a personal effort (Nurah)

I am a mechanical engineer. I am currently an MA student. Once I finish MA I will do PhD, God willing (Rafiq)

I am a student of medicine, fourth year. After graduation, God willing, I will do specialization (Faris)

These comments demonstrate a commitment to improvement through academic qualifications and personal effort, supported by religious faith. Here student culture can be seen overlapping with national culture.

Also evident in the data, connecting student culture to national culture, was a strong sense of being part of social networks, of friends and family. There were many references to students supporting each other and to the help of family. Faris, for example, said he spoke English to:

my friends, close friends. Their English level is similar to mine. They have the same goal for learning English. They are my townsmen. They attend university like myself. They have the desire to learn English. Together we speak English.

Similarly, Malikah said she spoke English:

to my friends, with my teachers on the facebook ... with some of my relatives. They study English. 
In terms of student culture mapping onto to national culture along language lines, most students said they spoke Arabic outside the classroom and that there were few occasions to speak English, as the following quotations illustrate:

Outside the class, there are very few opportunities. They are hardly mentioned. Maybe in this country I do not need to use English ... for my job I do not use it. Maybe for tourism or economy purposes, it is useful. But for my job in this country, I don't think I need English. (Mukhtar)

I don't use it much. Only in the class. (Bahiyah)

These quotations show clearly that, in this regard, student culture, and, by extension, youth culture, did not usually include English outside the classroom. Therefore, although there were many references to English for the purposes of study and work, as will be seen in later discussion, the medium of communication at Study University, evidenced in the students' responses, was mainly Arabic.

This raises interesting issues regarding where and how students used Arabic and English in thinking about and expressing ideas in their studies, and, as a corollary, the ways in which they used transitions from one language to the other in their learning. One of the questions in our interview schedule was about translation from English to Arabic and vice versa. It was noticeable that some students preferred to go directly to English, in order to bypass translation, since they knew they would need, subsequently, to be working in English, as the following quotation shows:

I need terminology in my study, and usually the terms used in English are more accurate than those in Arabic. In my study, the English term has many Arabic equivalents. I choose the English term that takes me to my target quickly. (Bahiyah)

By contrast, other students used translation from English to Arabic to help them understand concepts:

When I come across a difficult word that I can't understand, I translate it into Arabic so that I understand the topic better. This is both inside and outside the classroom. This is when I completely fail to understand it in English. (Rafiq)

I highly need this, especially with the computer, in the internet. Any product I come across, it has its instructions in English. I translate them into Arabic to understand about the product. (Nurah)

This issue of translation from English to Arabic, or vice versa, identifies the interchange of overlapping cultures, whereby the students belonged to a largely Arabic-speaking national culture, but used English a great deal for their studies. In this situation they developed their own strategies to address their learning needs. As these translation comments show, the interplay between languages in the student culture was often nuanced and dependent on context and the individual. A further point to note is that almost all references to languages spoken were to English or Arabic. There was one isolated reference to Russian and another to French. This means that students were not much exposed to other linguistic and cultural ideas; a situation that placed them on a continuum of linguistic experience between, for example, monolingual English-speaking students in the UK or America and plurilingual students in other parts of the world, such as Europe or India.

Student culture in general and in academic settings outside the classroom, was thus mainly reported as being conducted in Arabic. Exploration of the data showed the students belonged to a fairly homogeneous language group and that this mapped onto national language and culture. However, another feature of student culture evident in the responses spoke of internet and technology and showed the students connected to international youth culture through, for example, watching YouTube and films, or listening to songs. These were experienced mainly through English and showed student culture overlapping with youth culture across national boundaries.

Speaking and listening I may improve it through u tube. I search for videos and listen to them. (Rashidah)

I listen to a song and read the lyrics. When I come across a new word, I translate it. (Mukhtar)

Sometimes I watch English movies ... I hide subtitles to translate the movie into Arabic. (Malikah)

Thus student culture overlapped closely in language use onto national culture and was conducted through the medium of Arabic for most domains outside the classroom. Few students had been abroad. Youth culture was, to an extent, associated with English via the internet, listening to films, songs and YouTube, but it was also strongly associated with Arabic, the language used most of the time in students' everyday lives.

\section{Student Culture in Relation to Professional Academic Culture and Classroom Culture}

As expected, there were extensive references to the use of English connected with professional academic culture and classroom culture. This was particularly evident in association with the concept of English being a global language. 
Here, students recognised the need to know technical vocabulary in English and talked of research and professional resources in English in their subject fields. There was almost universal agreement that there should be more English in relation to their studies, with most of the students commenting that it was essential to be fluent in English for professional academic purposes.

Absolutely, because it is the language of the current time...all references about our specialization are in English. Any person who seeks to improve in their specialization must have a good command of English. (Asif)

Thus the general tenor of student culture in relation to professional academic culture was one towards English and away from Arabic, although there were some interesting instances, very few in number, where a student questioned the overriding presence of English in professional academic culture.

In my opinion, first and foremost, there must be focus on Arabic. For example, one of my friends while we were at university asked about the superlative form of an adjective. To be honest, he does not recognize the superlative form in Arabic, so how would he understand it in English? How can you deliver such an idea to him? (Najid)

My ambition is to continue my study. So I must learn English. Sometimes there are terms in Arabic that you can find only in English. So I feel forced to use English. (Akil)

A polarising attitude, towards or away, from English was noted by Albirini (2016) in survey data collected with students in Middle Eastern countries. In our data, with a modest sample of fifteen students, we saw a strong trend towards English in relation to professional academic culture. Nearly all students recognised the currency and necessity of that language; while Arabic was the language they used most of the time outside the classroom and in their everyday lives. As seen, there were very few comments which questioned the possible long-term effect on their ability to use academic Arabic.

A noticeable feature of classroom culture was the difference between the way students were generally taught English and how they used English for self-study, with the first being formal and more closed in approach, while the latter was informal and more open. Many students thought that the way they were taught English was not the most beneficial to their learning. They referred to an over-emphasis on the text book, to assessment as the main goal, and said there were too few opportunities to speak the language in a meaningful way. The following example illustrates these views:

they are teaching us Quest 2 textbook, which is spoken English-based. They teach it in an automated way. A student comes to the exam learning the answers by heart without understanding English. (Asif)

When there were positive experiences, these were very much appreciated.

It [English teaching] is very good. The teachers are very good. They focus most on [talking]. I like it very much. They focus on the four language skills... It was difficult for me at the first year at university. Now things are getting better. (Malikah)

With regard to English in their discipline area, students noted that English was integral to the classroom culture:

when there is specialist English taught, they should appoint an English teacher from the same specialization. In the first semester, our teacher was a civil engineer. We used to understand the ideas and learn the words. In the second semester, we had a teacher, his accent was excellent, but he would not focus on the specialised ideas. (Anwar)

since my study is information engineering, I come across a lot of specialist terms in English, for example, database. When I use these terms in Arabic, I feel I don't understand them properly, so I switch them into English immediately. (Rashidah)

mostly [English] when I do scientific research because in Arabic I cannot find research articles.(Najid)

A strong feature of student culture in relation to classroom culture was the way in which students emphasised the need to work hard and to achieve through independent self-study. As Nurah said, 'I consider personal effort the main factor for improving any language.' This was a frequent comment and there were numerous examples of ingenious ways by which the students improved their knowledge of English, both generally and specifically, for their studies.

It [technology] has a big role. You can join free courses. You can speak English on social media websites. You can download movies. You can translate a lot. It can help you with the correct pronunciation, how to pronounce a word. I use it a lot. (Najid) 
I used to read internet articles, news sites, like BBC. They are highly beneficial for reading. Also there was the reading of peer-reviewed scientific journals, since my specialization had to do with maintenance, the companies contracting with us used to send us periodically with every fair catalogues and scientific magazines. I used to read them. (Rafiq)

[I have improved my English ] through reading some stories, without understanding literally what they say, just get the general meaning of the text or the sentence... some words, some films. In some films I may not read the translation and try to get a general idea about what they are saying. (Akil)

For me it is an obsession, I translate any word I come across into English. (Nurah)

Whereas the data showed student culture outside the classroom in relation to national culture and youth culture to be conducted largely through Arabic, with little influence of other languages and few occasions to speak English, there was a different picture in relation to professional academic and classroom culture. These cultures contained extensive uses of English and a general statement of preference towards English by the students, on the basis of needing to speak English in order to communicate with the rest of the world and for work and study purposes. The students seemed comfortable with this situation and, as noted, their responses rarely questioned the potential negative effect on their knowledge of academic Arabic of using English to such an extent in their studies.

It subsumes all aspects of life, because this new life requires, first, technology and, second, English because English is the mother language of all world languages and learning it is very important for everybody in all aspects of life. (Wahid)

I heard about the learning of English in Egypt. English there is the basis for study. All their study and their subjects are in English. This gives them great support in English. This is very good for me.

- Does that badly affect Arabic as a language? Of course, this badly affects Arabic, but Arabic is already there. This makes a student unable to understand maths, sciences or anything else without English. (Mukhtar)

Firstly, it [English] helps me a lot in my study; secondly, it is good for social communication. Currently, most people speak English. If you want to travel to Turkey, if you know English, there is no need for you to learn Turkish. If you know English there is no need for any other language. (Faris)

\section{Conclusion}

Using Atkinson's (2004) model of overlapping cultures in an education context allowed us to examine issues of language use and preference in relation to English and Arabic in the Syrian higher education context. The data showed that the students were extensively engaged with both English and Arabic. They used English to access resources for their study, often drawing on the Internet and other media to improve their knowledge of the language. This, in turn, connected them with some aspects of international youth culture, such as music and film. Their connection to such youth culture was not otherwise much evident. The majority of students had either not travelled abroad, or travelled solely within the Middle Eastern countries. Some connections to youth culture existed, additionally, through family and friends who visited from abroad, or to whom they spoke via the Internet. Thus, student culture was expressed both in Arabic and English; and the language fault line lay, as previously discussed (Abdulkader \& Laugharne, 2009), on the borders of the classroom. The concept of classroom here should also include the virtual, since most of the students made extensive use the Internet in supporting them with their studies.

With regard to Arabic, this language was used in most interactions between students outside the classroom, in the university and in general society. Translation from English to Arabic was also employed for general academic understanding and to support learning. Overall, student culture in relation to national culture was strongly aligned with Arabic. There were occasional conflicting attitudes evident in language choices for English or Arabic, such as the difficulty a few students reported of finding Arabic terms in their discipline field, where this was their preference. Other students spoke of their decision to go directly to an English word, rather than engage with the Arabic term, as they knew they would need to learn the English, in any case, later in their studies. These instances highlight the tension between professional academic culture and national culture along lines of language use, although most of the students interviewed appeared to manage these choices with ease.

Overall, student culture at Study University was characterised by hard work, belief in self-improvement and religious faith. Our data showed the students used Arabic outside the classroom and in their everyday life and English for academic study and career opportunities. These findings broadly corroborated what we anticipated in exploring language use at Study University through Atkinson's (2004) model of overlapping cultures in an educational setting. 
Two aspects of student culture, however, surprised us. Travel is generally a feature of student culture in any country, but we had not expected the widespread aspiration to travel and study abroad which we found in the data. This aspiration was strongly associated with the use of English. In the context of Study University it was particularly striking, since most of the students had not travelled outside Syria. Similarly, the individual and enterprising ways students worked to improve their English was a notable feature, reflecting the extent and manner of their engagement with the Internet and other media. This was set in a context of strong family and social networks, where, for the majority of the time, Arabic was the language of communication.

There was rich detail in the data of how individual students at Study University negotiated between English and Arabic in the various cultures under discussion: national, student, youth, professional academic and classroom. As Atkinson and others have pointed out, the study of such cultures is complex and dynamic. Our data add further 'stitches' to Atkinson and Sohn's (2013) needle examining culture 'from the bottom up' (p.3), with a focus on language use. The students' voices in our study contribute further evidence of the need 'for a robust understanding in TESOL that people do live culturally, and how they do so.' Such understanding supports informed decisions about language planning and maintenance in higher education and about the role of languages, including English, in such settings.

\section{References}

Albirini, A. (2016). Modern Arabic Sociolinguistics: Diglossia, Codeswitching, Attitudes and Identity. London: Routledge.

Altbach, P. (2015). Perspectives on internationalizing higher education. International Higher Education(27), 6-8.

Atkinson, D. (2004). Contrasting rhetorics/contrasting cultures: Why contrastive rhetoric needs a better conceptualization of culture. Journal of English for Academic Purposes, 3(4), 277-289. http://dx.doi.org/10.1016/j.jeap.2004.07.002

Atkinson, D., \& Sohn, J. (2013). Culture from the Bottom Up. TESOL Quarterly, 47(4), 669-693. http://dx.doi.org/10.1002/tesq.104

Crystal, D. (2012). English as a global language. Cambridge: Cambridge University Press. http://dx.doi.org/10.1017/CBO9781139196970

Crystal, D. (2013). The language revolution. Chichester: John Wiley \& Sons.

De Witt, H. (2011). Globalisation and Internationalisation of Higher Education [introduction to online monograph]. doi.org/10.7238/rusc.v8i2.1247

Gupta, A., \& Ferguson, J. (1997). Culture, Power, Place: Explorations in Critical Anthropology: Duke University Press. http://dx.doi.org/10.1215/9780822382089

Holliday, A. (1994). Appropriate methodology and social context. Cambridge: Cambridge University Press.

Jackson, J. (2014). Introducing language and intercultural communication. London: Routledge.

Jenkins, J. (2015). Global Englishes: A resource book for students. London: Routledge.

Knight, J. (2015). International Universities: Misunderstandings and Emerging Models? Journal of Studies in International Education, 19(2), 107-121. http://dx.doi.org/10.1177/1028315315572899

Lightbown, P. M., \& Spada, N. (2013). How Languages are Learned (4th edition ed.). Oxford: Oxford University Press.

Mahboob, A. (2015). Identity Management, Language Variation and English Language Textbooks: Focus on Pakistan. In A. M. Dwi Noverini Djenar, Ken Cruickshank (Ed.), Language and Identity across Modes of Communication (pp. 153-177). Berlin: Mouton de Gruyter. http://dx.doi.org/10.1515/9781614513599.153

Martí, F. (2005). Words and worlds: World languages review. Clevedon: Multilingual Matters.

Montgomery, C. (2007). Researching the socio-cultural context of learning:'where many paths and errands meet?'. Research Intelligence, 101, 22-23.

Sowden, C. (2007). Culture and the 'good teacher' in the English Language classroom. ELT Journal, 61(4), 304-310. http://dx.doi.org/10.1093/elt/ccm049 


\section{Note}

Note 1. The research was carried out at a time when the war in Syria, which began in the Spring of 2011, was still continuing.

\section{Appendix. Interview Schedule}

1. Have you ever travelled abroad?

2. What languages do you speak?

3. How far are you in your present university study? What is your next step?

4. What are your general goals and objectives in learning English?

5. How have you reached your current level of English?

6. Can you tell me how your learning of English has improved to date? (writing, reading, speaking, listening)

7. Who do you normally speak English to?

8. Where do you use English?

9. Are there difficulties that challenge your knowledge of English?

10. What is the methodology used in learning English at your university?

11. Can you compare the way you learn English here to that of a country you visited or heard about? Which do you prefer?

12. How can language study be improved at university level?

13. What, in your view, is the role of technology in language learning, including the internet? Has it helped you?

14. Are there opportunities to use English outside the classroom? What are these?

15. Would you like to use English more in your studies?

16. In what situations do you translate from Arabic to English? (In your studies or outside the classroom)

17. Are there any situations in which you translate from English to Arabic (In your studies or outside the classroom)?

18. What are the different aspects of EAP in your opinion?

19. Could you recall a memorable event in learning English from school or university? Happy or sad incident,etc?

Thank you for your participation, which is much appreciated. 